Indo. J. Chem. Res., 2019, 7(1), 51-60

\title{
SINTESIS NANOPARTIKEL PERAK MENGGUNAKAN EKSTRAK DAUN SALAM (Syzygium polyanthum) SEBAGAI BIOREDUKTOR DAN UJI AKTIVITASNYA SEBAGAI ANTIOKSIDAN
}

\section{Synthesis of Silver Nanoparticles Using Syzygium polyanthum Extract as Bioreductor and the Application as Antioxidant}

\author{
Paulina Taba*, Nadya Yuli Parmitha, Syahruddin Kasim \\ ${ }^{I}$ Department of Chemistry, Faculty Mathematics and Natural Science, Hasanuddin University, \\ Jl. Perintis Kemerdekaan 90245, Makassar-Indonesia \\ *Corresponding author, e-mail: paulinataba@unhas.ac.id
}

Received: Apr. 2019 Published: Jul. 2019

\begin{abstract}
Silver nanoparticles have been synthesized by the reduction method using salam leaf extract (Syzygium polyanthum) as a reducing agent. The silver nanoparticles produced were then tested for their activity as antioxidants. The formation of silver nanoparticles was carried out by adding the leaf extract into the solution of $\mathrm{AgNO}_{3}$ and homogenized using a magnetic stirrer. A UV-Vis spectrophotometer was used to confirm the formation of silver nanoparticles. Particle Size Analyzer (PSA), Scanning Electron Microscope (SEM), X-Ray Diffractometer (XRD) and Fourir Transform Infra Red (FTIR) spectrometers were used to characterize the nanoparticles produced before being tested for antioxidant activity. The results showed that the absorbance value increased with increasing reaction contact time. The maximum uptake was obtained at wavelengths of 432-446 $\mathrm{nm}$ using a UV-Vis spectrophotometer. The particle size was determined using a PSA with an average particle size distribution of $45.7 \mathrm{~nm}$. The average diameter of silver nanoparticles was 10.06-13.97 nm and the silver nanoparticles had rod-shapes. Functional groups that play a role in the synthesis of nanoparticles were -OH$\mathrm{C}=\mathrm{O}$, and $-\mathrm{C}-\mathrm{O}$ groups. Silver nanoparticles inhibited free radicals as antioxidants with the $\mathrm{IC}_{50}$ value of 582.7 ppm.
\end{abstract}

Keywords: Antioxidants, reduction method, silver nanoparticles, Syzygium polyanthum.

\section{PENDAHULUAN}

Nanopartikel merupakan partikel yang memiliki ukuran 1-100 nm. Secara garis besar sintesis nanopartikel dapat dilakukan dengan metode top down (fisika) dan metode bottom up (kimia) (Wahyudi dan Rismayani, 2008). Namun, kedua metode ini menggunakan bahan kimia yang berlebihan yang dapat menyebabkan pencemaran lingkungan, dan membutuhkan biaya yang besar untuk pembuatannya. Oleh karena itu, suatu metode alternatif dikembangkan dalam sintesis nanopartikel atau nanomaterial berdasarkan konsep green chemistry yaitu metode green synthesis nanopartikel yang lebih ekonomis dan memiliki resiko pencemaran lingkungan yang rendah atau bahkan nol, sehingga produk yang dihasilkan lebih aman dan ramah lingkungan serta dapat digunakan dalam berbagai bidang termasuk kesehatan dan biomedis (Schmidt, 2007; Sharma dkk., 2009).
Metode green synthesis nanopartikel adalah metode sintesis yang membentuk nanopartikel logam dengan bantuan bahan alam yang berasal dari organisme (tumbuhan, dan mikroorganisme) baik darat maupun laut (Asmathunisha dan Kathiresan, 2013). Salah satu nanopartikel yang dapat disintesis dengan metode green synthesis adalah nanopartikel perak (Haryono dkk., 2008). Teknik bioreduksi dapat dilakukan dengan menggunakan mikroorganisme dalam preparasi nanopartikel. Tetapi, metode ini memerlukan pemeliharaan kultur yang sulit dan waktu sintesis yang lama sehingga tumbuhan menjadi alternatif sebagai bioreduktor dalam sintesis nanopartikel perak (Lembang dkk., 2013).

Beberapa jenis tumbuhan mengandung senyawa kimia tertentu yang dapat berperan sebagai bahan pereduksi dan saat ini penelitian yang berkaitan dengan sintesis nanopartikel perak dengan bahan dasar ion perak dan ekstrak tumbuhan telah banyak dilakukan. Lembang dkk. 
(2013) mensintesis nanopartikel perak yang berdiameter 40-80 $\mathrm{nm}$ dari ekstrak daun ketapang (Terminalia catappa). Matutu dkk. (2016) mensintesis nanopartikel perak yang berdiameter 35-43 $\mathrm{nm}$ dari ekstrak buah merah (Pandanus conoideus). Wahab dkk. (2018) mensintesis nanopartikel perak yang memiliki diameter 97,04 $\mathrm{nm}$ dari ekstrak daun kersen (Muntingia calabura L.). Ekstrak yang digunakan mengandung metabolit sekunder seperti terpenoid dan flavonoid yang memiliki aktivitas antioksidan sehingga ekstrak tersebut dapat berperan sebagai bioreduktor untuk menghasilkan nanopartikel perak.

Daun salam (Syzygium polyanthum) memiliki kandungan alkaloid, saponin, quinon, fenolik, triterpenoid, steroid dan flavonoid (Kusuma dkk., 2011; Hasanah, 2015; Widyawati, 2015; Widjajakusuma dkk., 2018; Hartanti dkk., 2019). Berdasarkan hasil penelitian, flavonoid merupakan salah satu kelompok senyawa fenolik yang bersifat antioksidan (John dkk., 2015; Yahia dkk., 2019) serta berperan dalam mencegah kerusakan sel dan komponen selularnya oleh radikal bebas reaktif (Saharan dkk., 2017). Peran antioksidan flavonoid terjadi dengan cara mendonasikan atom hidrogennya atau melalui kemampuannya mengkhelat logam, berada dalam bentuk glukosida (mengandung rantai samping glukosa) atau dalam bentuk bebas yang disebut aglikon (Hasanah, 2015). Menurut Bahriul dkk. (2014), ekstrak daun salam yang meliputi daun muda, daun setengah tua dan daun tua memiliki kemampuan antioksidan yang sangat kuat. Oleh karena itu, ekstrak daun salam mengandung bioreduktor sehingga eksrak ini berpotensi untuk menghasilkan nanopartikel logam seperti nanopartikel perak. Berdasarkan penelusuran literatur, pemanfaatan ekstrak daun ini untuk menghasilkan nanopartikel perak sampai saat ini belum dilakukan.

Berdasarkan uraian di atas, penelitian ini dilakukan untuk mensintesis nanopartikel perak dengan menggunakan ekstrak daun salam dan larutan $\mathrm{Ag}^{+}$. Optimasi konsentrasi larutan $\mathrm{Ag}^{+}$ dan komposisi larutan $\mathrm{Ag}^{+}$terhadap ekstrak daun salam dilakukan untuk memperoleh nanopartikel perak. Karakterisasi material yang dihasilkan dengan spektrofotometer UV-Vis, PSA, XRD, dan spektrometer FTIR menunjukkan bahwa nanopartikel perak telah berhasil disintesis dalam penelitian ini. Nanopartikel perak yang dihasilkan diuji aktifitasnya sebagai antioksidan. Hasil menunjukkan bahwa kemampuan nanopartikel perak yang diperoleh memiliki sifat oksidan yang lemah. Meskipun demikian, ekstrak daun salam memiliki potensi yang besar untuk mensintesis nanopartikel perak yang dapat dimanfaatkan untuk bidang lain.

\section{METODOLOGI}

\section{Alat}

Alat-alat yang digunakan dalam penelitian ini adalah peralatan gelas yang umum digunakan dalam laboratorium, corong Buchner, pompa vacuum, spektrofotometer UV-Vis 2600, Fourier Transform Infra Red (FTIR) Shimadzu 820 IPC, $X$-ray Diffraction (XRD), Particle Size Analysis (PSA), Scanning electron microscopy (SEM), rotary evaporator, multistireer, sentrifuge, frezze dry dan timbangan analitik.

\section{Bahan}

Bahan-bahan yang digunakan dalam penelitian ini adalah serbuk daun salam, akuabides, akuades, $\mathrm{AgNO}_{3}$ (Merck), kertas saring Whatman No. 42, tissue, kertas label, cling wrap dan aluminium foil.

\section{Prosedur Kerja \\ Preparasi dan Pembuatan Ekstrak Daun Salam}

Daun salam (Syzygium polyanthum) dicuci hingga bersih, kemudian dikeringkan, dipotongpotong hingga halus, kemudian ditimbang sebanyak $5 \mathrm{~g}$ daun salam kering dimasukkan ke dalam gelas kimia $250 \mathrm{~mL}$ dan ditambahkan 100 $\mathrm{mL}$ akuabides lalu dipanaskan hingga mendidih selama 15 menit kemudian didinginkan. Setelah mencapai suhu ruang, air rebusan dituang dan disaring menggunakan kertas saring whatman no. 42. Air rebusan tersebut selanjutnya dianalisis dengan menggunakan FTIR dan dapat digunakan langsung untuk proses sintesis nanopartikel perak dan uji aktivitas antioksidan dari nanopartikel yang diperoleh. 


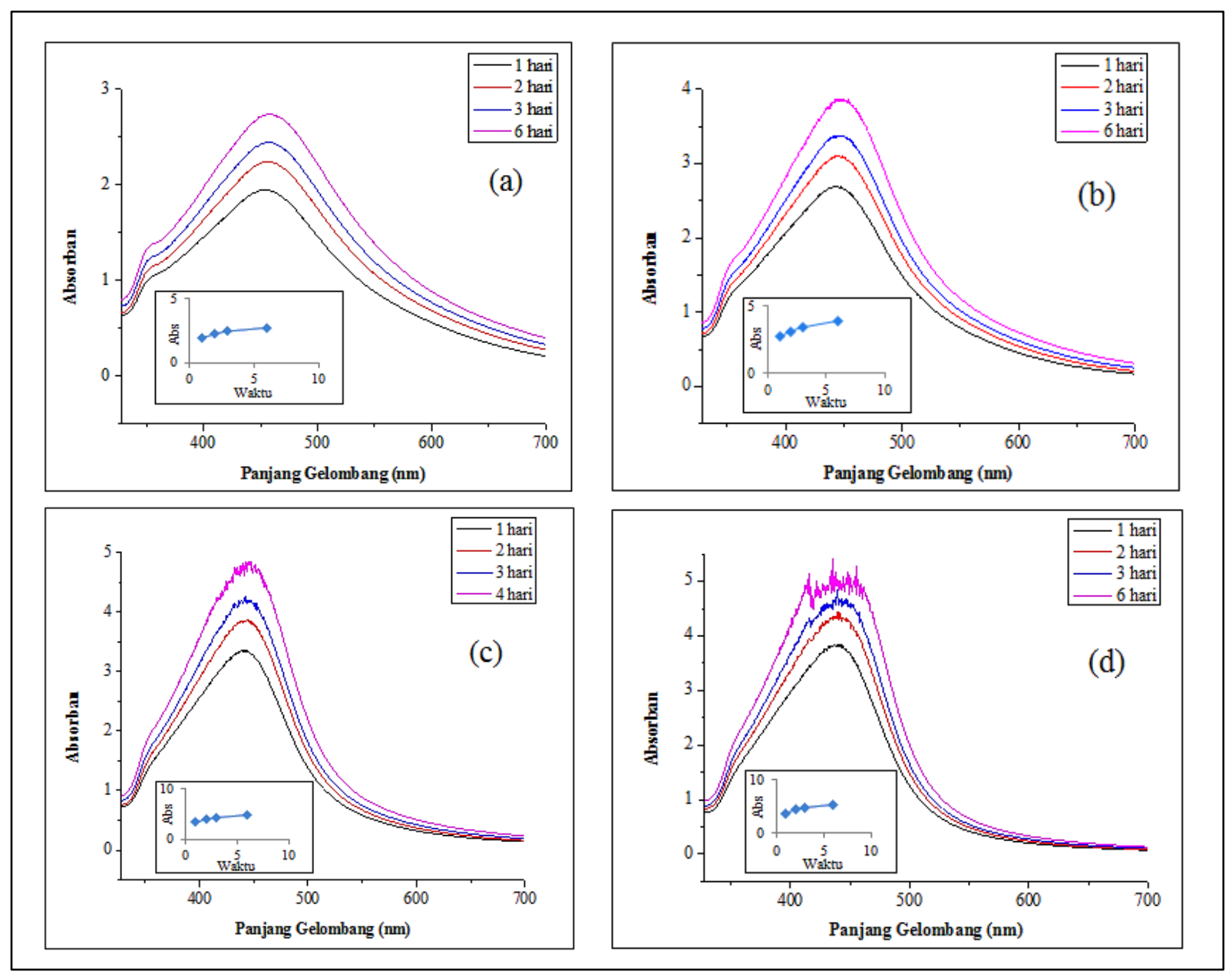

Gambar 1. Spektrum Serapan UV-Vis dari nanopartikel perak variasi konsentrasi $\mathrm{AgNO}_{3}$ (a) $0,5 \mathrm{mM}$, (b) $1 \mathrm{mM}$, (c) $1,5 \mathrm{mM}$ dan (d) $2 \mathrm{mM}$.

Pembuatan Larutan $\mathrm{AgNO}_{3}$ Variasi Konsentrasi $2 \mathrm{mM}, 1,5 \mathrm{mM}, 1 \mathrm{mM}$ dan 0,5 mM

Sebanyak 0,085 g serbuk $\mathrm{AgNO}_{3}$ dilarutkan ke dalam akuabides hingga volume $250 \mathrm{~mL}$ dan dicampurkan sampai homogen untuk membuat larutan $\mathrm{AgNO}_{3} 2 \mathrm{mM}$. Selanjutnya larutan dipipet sebanyak 37,$5 ; 25$; dan $12,5 \mathrm{~mL}$ dari larutan $\mathrm{AgNO}_{3} 2 \mathrm{mM}$ ke dalam labu ukur $50 \mathrm{~mL}$ dan ditambahkan akuabides hingga tanda batas untuk membuat konsentrasi $\mathrm{AgNO}_{3}$ 1,5; 1 ; dan $0,5 \mathrm{mM}$.

\section{Optimasi Konsentrasi Larutan $\mathbf{A g N O}_{3}$}

Larutan $\mathrm{AgNO}_{3} 2 ; 1,5 ; 1$ dan $0,5 \mathrm{mM}$ dipipet sebanyak $40 \mathrm{~mL}$ dan masing-masing larutan dimasukkan ke dalam Erlenmeyer 250 $\mathrm{mL}$, kemudian $1 \mathrm{~mL}$ ekstrak daun salam ditambahkan ke dalam erlenmeyer tersebut. Campuran diaduk dengan pengaduk magnetik selama 15 menit, kemudian dianalisis menggunakan UV-Vis.

Tabel 1. Hasil analisis serapan UV-Vis nanopartikel perak pada hari ke-1 larutan $\mathrm{AgNO}_{3}$ konsentrasi $2 \mathrm{mM}$.

\begin{tabular}{lll}
\hline Komposisi & $\begin{array}{l}\text { Panjang } \\
\text { Gelombang } \\
(\mathrm{nm})\end{array}$ & Absorban \\
\hline $1: 10$ & 469,5 & 10 \\
$1: 20$ & 434,5 & 5,032 \\
$1: 30$ & 432 & 3,316 \\
$1: 40$ & 432 & 2,641 \\
\hline
\end{tabular}

\section{Optimasi Komposisi Larutan $\mathrm{AgNO}_{3} 2 \mathrm{mM}$}

Ekstrak daun salam sebanyak $1 \mathrm{~mL}$ dipipet dan dimasukkan masing-masing ke dalam empat erlenmeyer $250 \mathrm{~mL}$, kemudian larutan $\mathrm{AgNO}_{3}$ $2 \mathrm{mM}$ sebanyak 10, 20, 30, dan $40 \mathrm{~mL}$ ditambahkan ke dalam masing-masing 
erlenmeyer. Campuran diaduk dengan pengaduk magnetik selama 15 menit, panjang gelombang dan absorbansi dianalisis dengan UV-Vis.

Tabel 2. Hasil analisis serapan UV-Vis nanopartikel perak

\begin{tabular}{lll}
\hline $\begin{array}{l}\text { Waktu } \\
\text { (Hari) }\end{array}$ & $\begin{array}{l}\text { Panjang } \\
\text { Gelombang }(\mathrm{nm})\end{array}$ & Absorban \\
\hline 1 & 432 & 3,316 \\
2 & 435 & 3,829 \\
3 & 437,5 & 4,121 \\
4 & 438 & 4,397 \\
7 & 442 & 4,757 \\
8 & 436,5 & 4,990 \\
9 & 446 & 5,124 \\
\hline
\end{tabular}

\section{Sintesis Nanopartikel Perak}

Larutan $\mathrm{AgNO}_{3}$ sebanyak $30 \mathrm{~mL}$ dicampur dengan $1 \mathrm{~mL}$ ekstrak daun salam kemudian campuran diaduk menggunakan pengaduk magnetik selama 15 menit dan disimpan dalam botol kaca.

Karakteristik larutan yang berupa warna, spektrum serapan UV-Vis dan $\mathrm{pH}$ setelah pencampuran pada waktu ke 1, 2, 3, 4, 7, 8, dan 9 hari dilakukan untuk mendapatkan waktu optimum. Setelah waktu optimum diperoleh, campuran pada waktu tersebut disentrifugasi kemudian dipisahkan. Larutannya dianalisis dengan PSA sedangkan padatannya dikeringkan dengan menggunakan frezze dryer untuk dikarakterisasi dengan alat XRD, SEM, FTIR dan diuji sifat antioksidannya.

\section{Uji Antioksidan}

\section{Pembuatan larutan induk Nanopartikel Perak 500 ppm}

Serbuk nanopartikel ditimbang sebanyak 0,005 g. Kemudian dilarutkan dengan metanol sampai $10 \mathrm{~mL}$.

\section{Pembuatan larutan induk ekstrak Daun Salam 500 ppm}

Daun salam ditimbang sebanyak $5 \mathrm{~g}$ kemudian ditambahkan akuabides hingga volumenya menjadi $100 \mathrm{~mL}$ untuk mendapatkan esktrak $50.000 \mathrm{ppm}$. Larutan ekstrak daun salam 50.000 ppm dipipet sebanyak $0,1 \mathrm{~mL}$, kemudian ditambahkan metanol hingga volumenya menjadi $10 \mathrm{~mL}$ untuk memperolah larutan ekstrak daun salam 500 ppm.

\section{Penentuan Aktivitas Antioksidan dengan Metode DPPH}

Uji aktivitas antioksidan dilakukan dengan metode efek perendaman terhadap radikal bebas N,N-diphenil-N-pikrilhydrazil (DPPH). Larutan induk $500 \mathrm{ppm}$ dipipet sebanyak 0,$1 ; 0,2 ; 0,4$; 0,$8 ; 1,6$ dan $3,2 \mathrm{~mL}$ untuk membuat variasi konsentrasi berturut-turut $10 ; 20 ; 40 ; 80 ; 160$ dan 320 ppm. Masing-masing larutan dimasukkan ke dalam tabung reaksi, kemudian 1 $\mathrm{mL}$ larutan DPPH 0,4 mM ditambahkan ke dalam tiap-tiap tabung reaksi. Volume dicukupkan sampai $5 \mathrm{~mL}$ dengan menggunakan metanol, kemudian larutan diinkubasikan pada suhu ruang selama 30 menit di ruang gelap. Serapan larutan diukur pada panjang gelombang maksimum $\left(\lambda_{\max }\right)$. Hasil penetapan antioksidan dibandingkan dengan vitamin $\mathrm{C}$ sebagai kontrol positif. Besar daya antioksidan dihitung dengan rumus:

$\%$ Aktivitas Antioksidan $=\frac{\text { Absorbansi Kontrol - Absorbansi Sampel }}{\text { Absorbansi Kontrol }} \times 100 \%$

Penentuan $\mathrm{IC}_{50}$ dilakukan dengan memplot konsentrasi sampel dan persen inhibisi masingmasing pada sumbu $\mathrm{x}$ dan $\mathrm{y}$ pada persamaan regresi linear. Nilai $\mathrm{IC}_{50}$ dinyatakan dengan nilai y sebesar 50 dan nilai $x$ yang akan diperoleh sebagai $\mathrm{IC}_{50}$. Nilai $\mathrm{IC}_{50}$ menyatakan besarnya konsentrasi larutan sampel yang dibutuhkan untuk mereduksi radikal bebas DPPH sebesar $50 \%$.

\section{HASIL DAN PEMBAHASAN}

\section{Sintesis Nanopartikel Perak Optimasi Konsentrasi Larutan $\mathrm{AgNO}_{3}$}

Spektrum serapan UV-Vis dari nanopartikel perak sebagai fungsi konsentrasi larutan $\mathrm{AgNO}_{3}$ dapat dilihat pada Gambar 1. Pengukuran absorbansi larutan dilakukan pada kisaran panjang gelombang 200-700 $\mathrm{nm}$. Gambar 3 menunjukkan bahwa panjang gelombang dan absorbansi dari nanopartikel perak bertambah dengan bertambahnya waktu. Nanopartikel perak dengan variasi konsentrasi larutan $\mathrm{AgNO}_{3}$ menunjukkan semakin kecil konsentrasi larutan $\mathrm{AgNO}_{3}$ yang digunakan maka semakin besar panjang gelombang dan semakin kecil absorbansi yang terbentuk. 


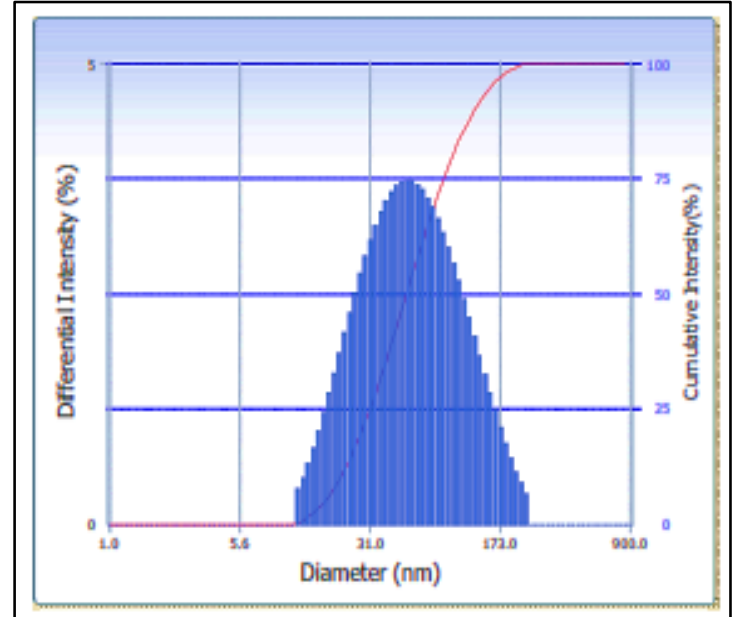

(a)

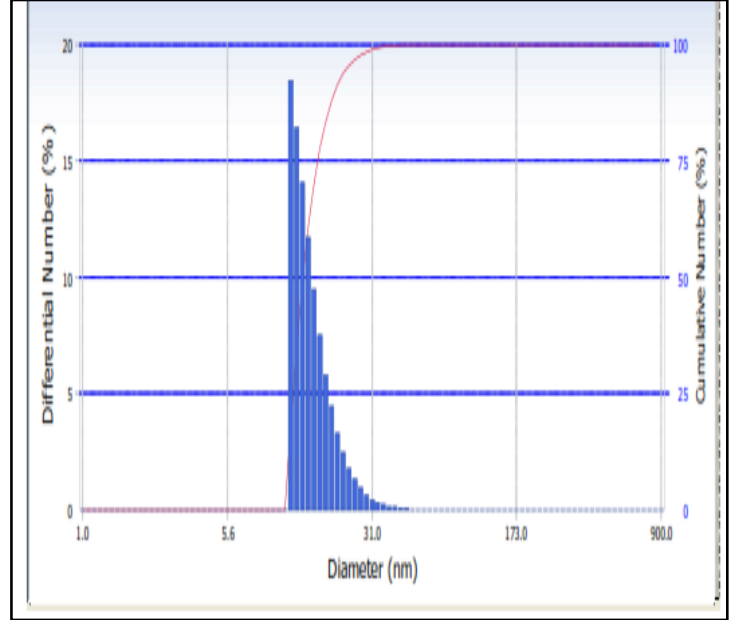

(b)

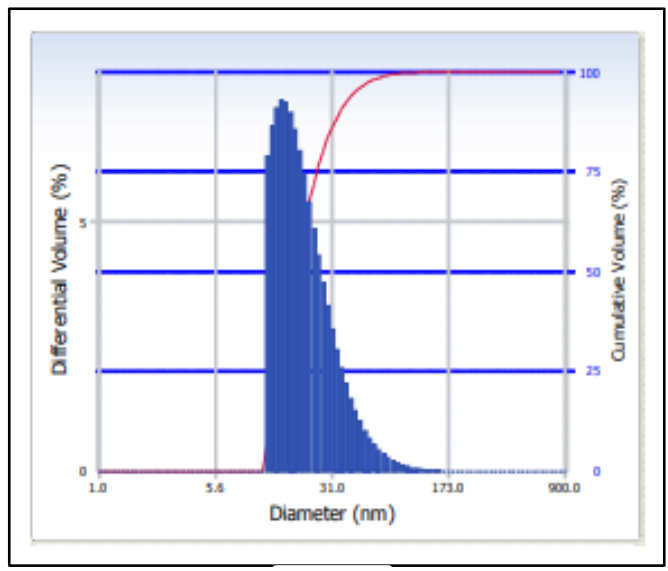

(c)

Gambar 2. Hasil analisis PSA nanopartikel perak, histogram dispersi ukuran (a) dengan intensitas, (b) dengan nomor dan (c) dengan volume.

Nanopartikel perak dengan ukuran terkecil ditandai dengan panjang gelombang kecil dan absorbansi yang paling besar. Dari keempat variasi konsentrasi larutan $\mathrm{AgNO}_{3}$ yang memiliki panjang gelombang paling kecil dan absorbansi yang besar adalah konsentrasi $2 \mathrm{mM}$. Sehingga konsentrasi larutan $\mathrm{AgNO}_{3}$ yang digunakan untuk sintesis nanopartikel perak dalam skala besar adalah konsentrasi $2 \mathrm{mM}$.

\section{Optimasi Komposisi Larutan $\mathrm{AgNO}_{3}$}

Hasil analisis serapan UV-Vis nanopartikel perak pada hari ke-1 dapat dilihat pada Tabel 1. Panjang gelombang maksimum bervariasi dari 432-469,5 nm dengan variasi komposisi larutan $\mathrm{AgNO}_{3}$ terhadap ekstrak daun salam. Data ini menunjukkan bahwa nanopartikel perak dihasilkan pada semua komposisi yang dihasilkan. Semakin besar komposisi larutan
$\mathrm{AgNO}_{3} 2 \mathrm{mM}$ terhadap ekstrak daun salam yang digunakan maka semakin kecil panjang gelombang dan absorbansi yang dihasilkan. Komposisi larutan $\mathrm{AgNO}_{3} 2 \mathrm{mM}$ yaitu 1:10 dan 1:20 memiliki panjang gelombang dan absorbansi yang besar dibandingkan dengan komposisi 1:30 dan 1:40 yang menunjukkan kemungkinan terjadinya aglomerasi dan membentuk warna kehitaman. Komposisi 1:30 dan 1:40 memiliki panjang gelombang yang sama pada hari ke-1 sehingga komposisi dengan absorbansi yang paling besar (1:30) dipilih untuk sintesis nanopartikel perak dalam jumlah besar.

\section{Karakterisasi Nanopartikel Perak Studi Kestabilan Nanopartikel Perak dengan Spektrofotometer UV-Vis}

Tabel 2 menunjukkan panjang gelombang dan absorbansi dari nanopartikel perak sebagai 
fungsi waktu. Panjang gelombang maksimum yang dihasilkan bervariasi dari $432-446 \mathrm{~nm}$ yang menunjukkan terbentuknya nanopartikel perak pada semua waktu yang digunakan. Perubahan panjang gelombang tidak terlalu besar dari hari 1 sampai hari ke-9. Hal ini menunjukkan bahwa nanopartikel perak yang dihasilkan cenderung stabil. Waktu reaksi sangat mempengaruhi nanopartikel perak yang terbentuk. Absorbansi berhubungan dengan jumlah nanopartikel yang terbentuk. Hasil menunjukkan bahwa absorbansi dari hari 1 meningkat sampai hari ke-9.

Untuk penelitian lebih lanjut, waktu yang

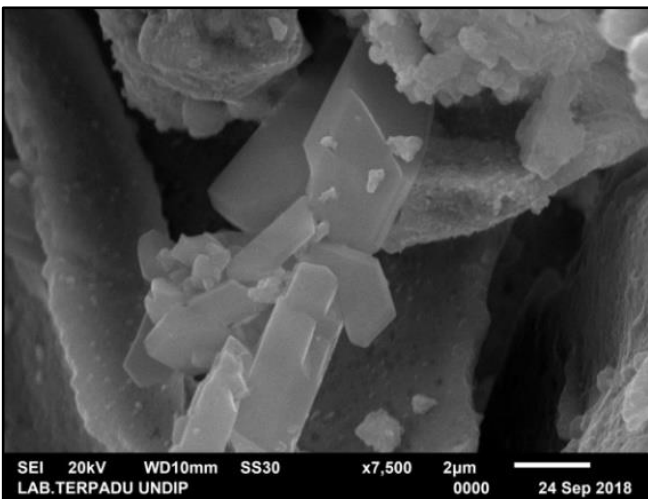

(a) berhasil disintesis yaitu 45,7 $\mathrm{nm}$. Hasil karakterisasi ini mendukung hasil yang diperoleh dengan menggunakan spektrovotometer UV. Ukuran dalam skala nano yang dihasilkan membuktikan bahwa ekstrak daun salam memiliki potensi sebagai agen pereduksi dalam sintesis nanopartikel.

\section{Morfologi Nanopartikel Perak dengan SEM}

Hasil Analisis dengan SEM ditunjukkan pada Gambar 3. Hasil SEM nanopartikel perak menunjukkan bahwa morfologi nanopartikel perak memiliki struktur permukaan yang halus

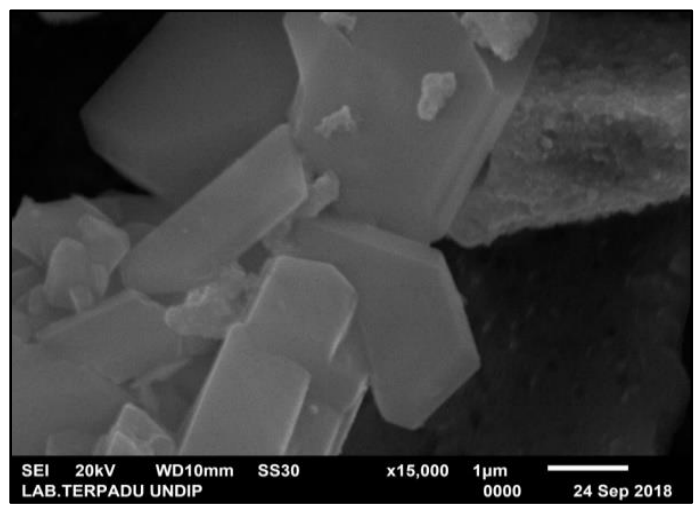

(b)

Gambar 3. Hasil analisis sampel nanopartikel perak dengan menggunakan SEM pada (a) skala $2 \mu \mathrm{m}(7,500 \mathrm{x})$ dan (b) skala $1 \mu \mathrm{m}(15,000 \mathrm{x})$.

dipilih adalah 8 hari (waktu optimum) karena pada waktu tersebut, nanopartikel perak yang dihasilkan memiliki panjang gelombang yang lebih kecil dan absorbansi yang lebih besar dibandingkan dengan hari sebelumnya. Pada hari ke-9 panjang gelombang nanopartikel perak meningkat dengan meningkatnya absorbansi.

\section{Ukuran Nanopartikel Perak dengan Particle Size Analyzer}

Metode pengukuran partikel dengan PSA dinilai lebih akurat dalam menentukan distribusi ukuran partikel. Hasil penentuan distribusi ukuran nanopartikel perak dengan menggunakan PSA ditunjukkan pada Gambar 2. Data ukuran partikel yang diperoleh berupa tiga distribusi yaitu intensitas, nomor dan volume, sehingga dapat menggambarkan keseluruhan kondisi sampel (Nikmatin dkk., 2011). Hasil karakterisasi dengan menggunakan PSA menunjukkan secara keseluruhan rata-rata ukuran diameter nanopartikel perak yang telah dengan partikel yang tidak seragam dan berbentuk batang agak memanjang. Ukuran partikel yang tidak seragam ditunjukkan pada perbesaran 7.500 kali dengan ukuran partikel yaitu 1,$25 ; 2,5 ; 3,25$; dan $3,5 \mu \mathrm{m}$. Sedangkan pada perbesaran 15.000 kali dengan ukuran partikel yaitu $1 ; 1,37 ; 1,5$; dan $2,5 \mu \mathrm{m}$. Hasil karakterisasi ini membuktikan bahwa perak yang dihasilkan memiliki ukuran nano seperti dihasilkan dari karakterissi dengan menggunakan spektrovotometer UV. Keberagaman ukuran partikel yang diperoleh juga dilaporkan oleh oleh Masakke dkk. (2014) yang menyatakan bahwa nanopartikel perak yang dihasilkan memiliki ukuran yang bervariasi akibat efek dari agregasi nanopartikel dan memiliki partikel yang tidak seragam.

\section{Karakterisasi Nanopartikel Perak dengan FTIR \\ Spektrum FTIR ekstrak daun salam dan nanopartikel perak ditunjukkan pada Gambar 4.}




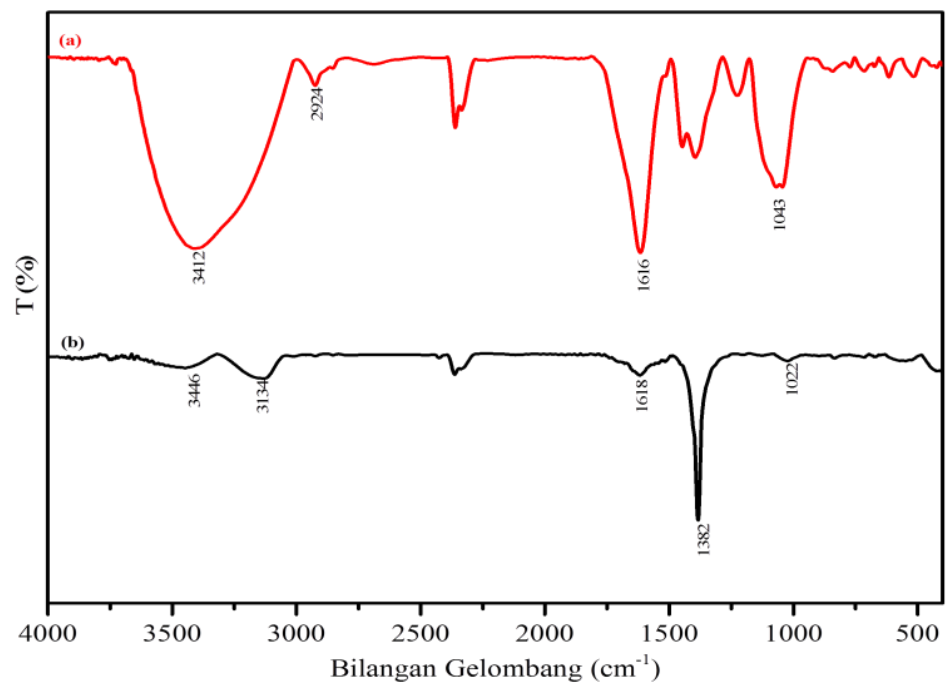

Gambar 4. Spektrum FTIR a) Ektrak Daun Salam b)

Nanopartikel Perak.

Spektrum FTIR tersebut menunjukkan adanya gugus fungsional yang berbeda. Pita serapan dari ekstrak daun salam pada (Gambar 4 a) $3412 \mathrm{~cm}^{-1}$ adalah karakteristik dari vibrasi peregangan $\mathrm{O}-\mathrm{H}$ yang berasal dari kelompok senyawa yang terkandung dalam senyawa flavonoid, tanin, terpenoid, saponin dan polifenol. Ciri umum senyawa fenolik diindikasikan oleh adanya serapan pada daerah bilangan gelombang $1616 \mathrm{~cm}^{-1}$ yaitu serapan $\mathrm{C}=\mathrm{O}$. Bilangan gelombang 1043-1068 $\mathrm{cm}^{-1}$ merupakan gugus C-O. Pita serapan dari bilangan gelombang $2924 \mathrm{~cm}^{-1}$ menunjukkan adanya vibrasi peregangan $\mathrm{C}-\mathrm{H}$. Pita serapan dari nanopartikel perak pada (Gambar 4b) bilangan gelombang $3446 \mathrm{~cm}^{-1}$ menunjukkan adanya vibrasi peregangan $\mathrm{O}-\mathrm{H}$. Bilangan gelombang $3134 \mathrm{~cm}^{-1}$ menunjukkan adanya gugus $\mathrm{Csp}_{2} \mathrm{H}$. Bilangan gelombang $1618 \mathrm{~cm}^{-1}$ menunjukkan adanya gugus $\mathrm{C}=\mathrm{O}$. Bilangan gelombang 1382 $\mathrm{cm}^{-1}$ menunjukkan adanya vibrasi peregangan $\mathrm{C}$ O. Bilangan gelombang $1022 \mathrm{~cm}^{-1}$ menunjukkan adanya gugus $\mathrm{C}-\mathrm{O}$ bending.

Gambar 4 menunjukkan adanya pergeseran bilangan gelombang menunjukkan bahwa terjadi interaksi antara gugus fungsi dengan nanopartikel. Pergeseran spektrum dari ekstrak daun salam setelah pembentukan nanopartikel perak yakni pada gugus $\mathrm{O}-\mathrm{H}, \mathrm{C}=\mathrm{O}$ dan $\mathrm{C}-\mathrm{O}$ yang menunjukkan bahwa gugus-gugus ini berperan dalam reaksi reduksi logam perak.

\section{Karakterisasi Nanopartikel Perak dengan XRD}

Karakterisasi nanopartikel perak dengan menggunakan XRD untuk mendukung pembuktian bahwa nanopartikel yang disintesis adalah murni nanopartikel perak. Hasil XRD nanopartikel perak ditunjukkan pada Gambar 5. Gambar 5 memperlihatkan pola difraksi XRD yang dihasilkan oleh nanopartikel perak yang disintesis menggunakan ekstrak daun salam setelah $\mathrm{Ag}^{+}$mengalami reduksi menjadi $\mathrm{Ag}^{\circ}$. Difraktogram yang dihasilkan menunjukkan puncak yang cukup tajam yang membuktikan telah terbentuk nanopartikel perak. Hal ini ditunjukkan oleh nilai $2 \theta$ dari nanopartikel perak berturut-turut yaitu 37,$76 ; 43,98 ; 64,30$ dan 77,31 yang mendekati data difraktogram perak standar yaitu 38,11; 44,30, 64,44 dan 77,40. Indeks miller masing-masing (111), (200), (202) dan (311).

Tabel 3. Data Difraktogram XRD Nanopartikel Perak

\begin{tabular}{llll}
\hline 2-theta & FWHM & $\begin{array}{l}\text { Indeks } \\
\text { Miller }\end{array}$ & $\begin{array}{l}\text { Ukuran } \\
\text { (nm) }\end{array}$ \\
\hline 37,76 & 0,92 & 111 & 10,06 \\
43,98 & 0,77 & 200 & 12,17 \\
64,30 & 0,73 & 202 & 13,97 \\
77,31 & 0,98 & 311 & 11,61 \\
\hline
\end{tabular}


Dari difraktogram terdapat puncak selain puncak khas nanopartikel perak, hal ini menandakan bahwa nanopartikel perak yang dihasilkan masih mengandung pengotor atau belum murni $100 \%$ nanopartikel perak. Data difraktogram (Tabel 3) juga memberikan informasi distribusi ukuran butir nanopartikel konsentrasi dapat dilihat pada Tabel 4. Berdasarkan aktivitas antioksidan ekstrak daun salam dan nanopartikel perak menunjukkan bahwa semakin besar konsentrasi (ppm) yang digunakan maka semakin besar aktivitas antioksidannya.

Aktivitas antioksidan ekstrak daun salam

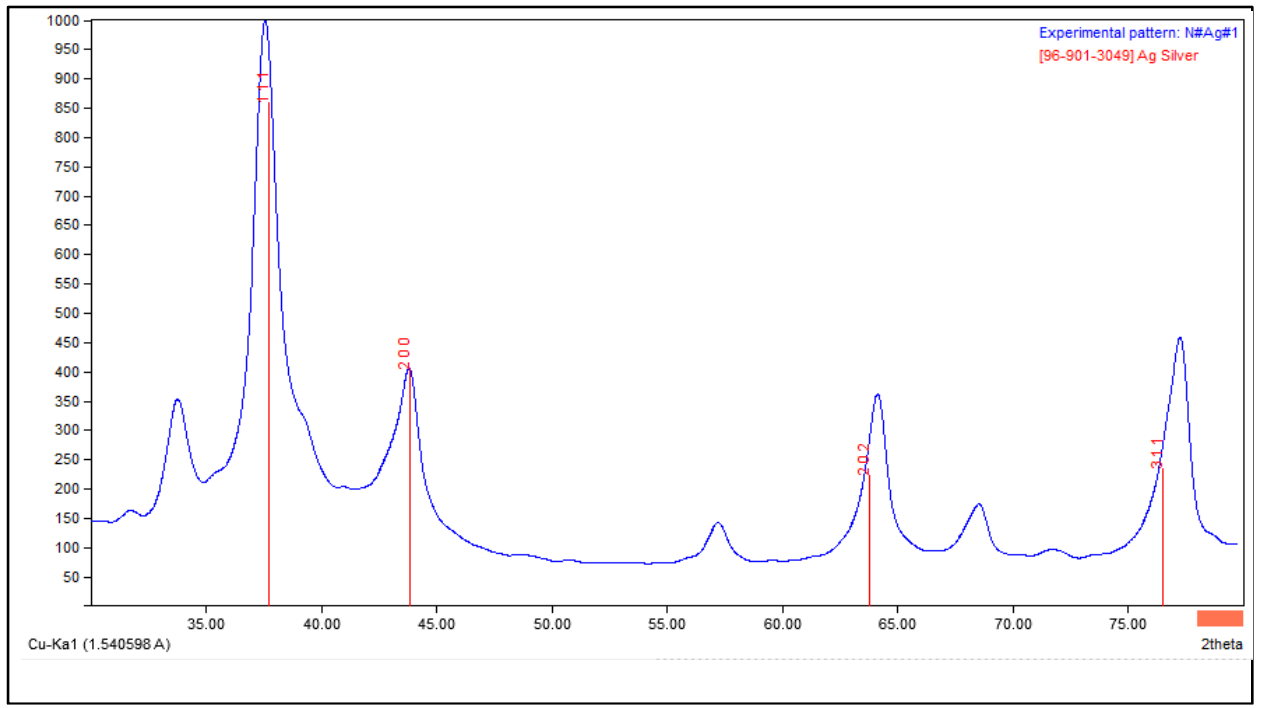

Gambar 5. Difraktogram XRD nanopartikel perak

perak. Distribusi ukuran nanopartikel perak yang berhasil disintesis memiliki ukuran yang bervariasi yakni 10,06-13,97 $\mathrm{nm}$.

Hasil ini mendukung analisis dengan spektrofotometer UV yang menunjukkan bahwa nanopartikel perak terbentuk dengan menggunakan bioresuktor dari ekstrak daun salam.

Tabel 4. Aktivitas Antioksidan Ekstrak Daun Salam dan NPAg

\begin{tabular}{llll}
\hline \multicolumn{4}{c}{ Salam dan NPAg } \\
\cline { 3 - 4 } No & $\begin{array}{l}\text { Konsentrasi } \\
(\mathrm{ppm})\end{array}$ & $\begin{array}{l}\text { Ekstivitas antioksidan } \\
\text { Salam }\end{array}$ & NPAg \\
\hline 1 & 10 & 5,75 & 4,63 \\
2 & 20 & 7,95 & 5,43 \\
3 & 40 & 21,16 & 6,86 \\
4 & 80 & 39,66 & 10,16 \\
5 & 160 & 70,78 & 16,58 \\
\hline
\end{tabular}

Uji Aktivitas Antioksidan Nanopartikel Perak

Antioksidan merupakan zat yang mampu memperlambat atau mencegah proses oksidasi yang disebabkan oleh radikal bebas. Hasil pengukuran aktivitas antioksidan ekstrak daun salam dan nanopartikel perak dengan variasi lebih besar dibandingkan dengan aktivitas antioksidan nanopartikel perak. Adapun aktivitas antioksidan senyawa pembanding yaitu vitamin $\mathrm{C}$ dapat terlihat pada Tabel 5.

Tabel 5. Nilai Aktivitas Antioksidan Vitamin C sebagai Pembanding

\begin{tabular}{ccc}
\hline & \multirow{2}{*}{$\begin{array}{c}\text { Konsentrasi } \\
(\mathrm{ppm})\end{array}$} & $\begin{array}{c}\text { \%Aktivitas } \\
\text { Antioksidan }\end{array}$ \\
\cline { 3 - 3 } & & Vitamin C \\
\hline 1 & 0,25 & 35,18 \\
2 & 0,5 & 37,65 \\
3 & 1 & 41,97 \\
4 & 2 & 53,08 \\
5 & 4 & 74,07 \\
\hline
\end{tabular}

Vitamin $\mathrm{C}$ yang digunakan sebagai pembanding atau kontrol positif memiliki aktivitas antioksidan jauh lebih besar dari ekstrak daun salam dan nanopartikel perak yaitu pada konsentrasi $4 \mathrm{ppm}$ sebesar $74,07 \%$. Nilai $\mathrm{IC}_{50}$ berbanding terbalik dengan aktivitas antioksidan dari ekstrak daun salam dan nanopartikel perak. Semakin besar aktivitas antioksidannya maka semakin kecil nilai $\mathrm{IC}_{50}$. $\mathrm{IC}_{50}$ merupakan nilai yang menunjukkan kemampuan penghambatan 
$50 \%$ radikal bebas oleh suatu konsentrasi sampel (ppm) (Mailandari, 2012). Hasil Nilai $\mathrm{IC}_{50}$ dari ekstrak daun salam, nanopartikel perak dan vitamin $\mathrm{C}$ dapat dilihat pada Tabel 6.

Berdasarkan nilai $\mathrm{IC}_{50}$ diatas, nanopartikel perak memiliki daya antioksidan yang sangat lemah yang dapat dilihat dari nilai $\mathrm{IC}_{50}$ yakni 582,66 ppm dibandingkan dengan ekstrak daun salam dengan nilai $\mathrm{IC}_{50}$ yaitu $109,64 \mathrm{ppm}$ yang daya antioksidannya sedang yang dipengaruhi oleh banyaknya senyawa antioksidan yang terdapat dalam ekstrak daun salam seperti flavonoid, saponin, steroid dan alkaloid dibandingkan dengan nanopartikel perak yang memiliki gugus fungsi tertentu dan nanopartikel perak yang terbentuk memiliki ukuran yang cukup besar sehingga memungkinkan aktivitas antioksidannya sangat lemah. Nilai $\mathrm{IC}_{50}$ diperoleh dari beberapa tahapan yaitu menghitung nilai konsentrasi dan nilai inhibisi untuk masing-masing persentase aktivitas penghambat radikal bebas DPPH dari ekstrak daun salam, nanopartikel perak dan vitamin C.

Tabel 6. Nilai $\mathrm{IC}_{50}$ dari Ekstrak Daun Salam, Nanopartikel Perak dan Vitamin C

\begin{tabular}{|c|c|c|}
\hline Sampel & $\begin{array}{c}\text { Nilai IC }_{50} \\
\text { (ppm) }\end{array}$ & $\begin{array}{c}\text { Daya } \\
\text { Antioksidan }\end{array}$ \\
\hline $\begin{array}{c}\text { Ekstrak } \\
\text { Daun Salam }\end{array}$ & 109,637 & Sedang \\
\hline $\begin{array}{c}\text { Nanopartikel } \\
\text { Perak }\end{array}$ & 582,657 & $\begin{array}{l}\text { Sangat } \\
\text { Lemah }\end{array}$ \\
\hline Vitamin C & 1,727 & Sangat Kuat \\
\hline
\end{tabular}

Beberapa penelitian telah dilakukan terkait dengan uji aktivitas nanopartikel perak. Bunghez dkk. (2012) memperoleh hasil aktivitas antioksidan nanopartikel perak dari ekstrak Hyacinthus orientalis yaitu $88,30 \%$ dan hasil aktivitas antioksidan dari ekstrak Dianthus caryophyllus yaitu 97,38\%.

\section{KESIMPULAN}

Berdasarkan hasil penelitian dapat disimpulkan bahwa ekstrak daun salam (Syzygium polyanthum) mampu berfungsi sebagai bioreduktor dalam proses sintesis nanopartikel perak. Sintesis nanopartikel dengan ekstrak daun salam (Syzygium polyanthum) menghasilkan nanopartikel perak berwarna kuning kecoklatan yang memiliki panjang gelombang 432-446 $\mathrm{nm}$ berbentuk batang agak memanjang dengan diameter rata-rata sebesar 45,7 nm. Ekstrak daun salam (Syzygium polyanthum) memiliki aktivitas sebagai antioksidan dengan nilai IC50 yaitu 109,637 ppm dan nanopartikel perak dengan $\mathrm{IC}_{50}$ yaitu $582,657 \mathrm{ppm}$.

\section{DAFTAR PUSTAKA}

Asmathunisha, N., Kathiresan, K., 2013, A Review on Biosynthesis of Nanoparticles by Marine Organisms, Colloids Surf., B, 103, 283-287.

Bahriul, P., Rahman, N., Diah, A. W. M., 2014, Uji Aktivitas Antioksidan Ekstrak Daun Salam (Syzygium polyanthum) dengan Menggunakan 1,1-Difenil-2-Pikrilhidrazil, J. Akad. Kim., 3(3), 143-149.

Bunghez, I. R., Patrascu, M. E. B., Badea, N., Doncea, S. M., Popescu, A., Ion, R. M., 2012. Antioxidant Silver Nanoparticles Green Synthesized using Ornamental Plants, J. Optoelectronics Adv. Mater., 11(14), 1016-1022.

Haryono, A., Sondari, D., Harmami, S. B., Randy, M., 2008, Sintesa Nanoparikel Perak dan Potensi Aplikasinya, J. Ris. Ind., 2(3), 155-163.

Hartanti, L., Yonas, S.M.K., Mustamu, J.J., Wijaya, S., Setiawan, H.K., and Soegianto, L., 2019, Influence of extraction methods of bay leaves (Syzygium polyanthum) on antioxidant and HMG-CoA Reductase inhibitory activity, Heliyon, 5, 1-14.

Hasanah, N., 2015, Aktivitas Antioksidan Ektrak Etanol Daun Salam, J. Pena Medika, 5(1), 55-59.

John, K.M.M., Ayyanar , M., Arumugam , T., Enkhtaivan , G., Jin, K., and Kim, D.H., 2015, Phytochemical screening and antioxidant activity of different solvent, extracts from Strychnos minor Dennst leaves, Asian Pac., J. Trop. Dis., 5(3), 204209.

Kusuma, I.W., Kuspradini, H., Arung, E.T., Aryani , F., Min , Y.-H., Kim, Y.-U., Biological Activity and Phytochemical Analysis of Three Indonesian Medicinal Plants, Murraya koenigii, Syzygium polyanthum and Zingiber purpurea, $J$. Acupunct. Meridian Stud., 4(1),75-79 
Lembang, E. Y., Maming, Zakir, M., 2013, Sintesis Nanopartikel Perak dengan Metode Reduksi Menggunakan Bioreduktor Ekstrak Daun Ketapang (Terminalia catappa), Repository, Universitas Hasanuddin, Makassar.

Mailandari, M., 2012, Uji Aktivitas Antioksidan Ekstrak Daun Garcinia kydia roxb dengan Metode DPPH dan Identifikasi Senyawa Kimia Fraksi yang Aktif, Skripsi Tidak Diterbitkan, Universitas Indonesia, Depok.

Masakke, Y., Rasyid, M., Sulfikar, 2014, Biosintesis Nanopartikel Perak Menggunakan Ekstrak Metanol Daun Manggis (Garcinia mangostana L.), J. Chem., 5(2), 45-57.

Nikmatin, S., Maddu, A., Purwanto, S., Mandang, T., Purwanto A., 2011, Analisa Struktur Mikro Pemanfaatan Limbah Kulit Rotan Menjadi Nanopartikel Selulosa Sebagai Pengganti Serat Sintetis, J. Biofis., 7(1), 41-49.

Saharan, P., Sadh, P.K., and Duhan, J. S., 2017, Comparative assessment of effect of fermentation on phenolics, flavanoids and free radical scavenging activity of commonly used cereals, Biocat. Agric. Biotechnol., 12, 236-240.

Schmidt, K. F., 2007, Green Nanotechnology: It's Easier Than You Think. Project on Emerging Nanotechnology, Woodwraw Wilson International Center for Scholars, 8, $1-36$.

Sharma, V. K., Yngard, R. A., Lin, Y., 2009, Silver Nanoparticles: Green Synthesis and their Antimicrobial Activities, Adv. Colloid and Interface Sci., 145(1-2), 83-96.
Wahab, A., W., Abdul Karim, Nursiah La Nafie, Nurafni, I W. Sutapa, 2018, Synthesis of Silver Nanoparticles Using Muntingia Calabura L. Leaf Extract As Bioreductor and Applied As Glucose Nanosensor, Oriental J. Chem., 34(6), 3088-3094.

Wahyudi, T., dan Rismayani, S., 2008, Aplikasi Nanoteknologi pada Bidang Tekstil, Arena Tekstil, 23(2), 52-109.

Widjajakusuma, E.C., Jonosewojo, A., Hendriati, L., Wijaya, S., Ferawati, XX , Surjadhana, A., and Sastrowardoyo, W., Monita, N., Muna, N.M., Fajarwati, R.P., Ervina, M., Esar, S.Y., Soegianto, L., Lang, T., and Heriyanti, C., 2018, Phytochemical screening and preliminary clinical trials of the aqueous extract mixture of Andrographis paniculata (Burm. f.) Wall. ex Nees and Syzygium polyanthum (Wight.) Walp leaves in metformin treated patients with type 2 diabetes, Phytomedicine, 55, 137-147.

Widyawati, T., Yusoff, N.A., Asmawi, M.Z., and Ahmad, M, 2015, Antihyperglycemic Effect of Methanol Extract of Syzygium polyanthum (Wight.) Leaf in Streptozotocin-Induced Diabetic Rats, Nutrients, 7, 7764-7780.

Yahia, Y., Bagues , M., Zaghdoud , C., Al-Amri , S.M., Nagaz, K., and Guerfel, M., 2019, Phenolic profile, antioxidant capacity and antimicrobial activity of Calligonum arich L., desert endemic plant in Tunisia, South African J. Botany, 124, 414-419. 